\title{
ICE FABRICS AND PETROGRAPHY, MESERVE GLACIER, ANTARCTICA*
}

\author{
By P. W. Anderton† \\ (Institute of Polar Studies, Ohio State University, Columbus, Ohio 432 ro, U.S.A.)
}

\begin{abstract}
Aвstract. Results of petrographic and fabric analysis of fine-grained cold ice from the tongue of Meserve Glacier, Antarctica, are described. Most of the basal ice is remarkably uniform in texture and shows an optic-axis fabric with a single strong maximum, which is consistent with the steady-state conditions of flow. Within $0.5 \mathrm{~m}$ of the ice-rock interface, irregularities in the bed cause flow perturbations which are correlated with recrystallization and changes in fabric of the ice. Optic-axis fabrics in the basal ice show close symmetry relationships with dimensional fabric and deformation symmetry. Grain-size of the ice increases towards the surface of the glacier and the single maximum of the optic-axis fabric undergoes a rotation about the flow vector. In the near surface, where strain-rates are relatively much lower, the optic-axis fabric symmetry is not closely related to either deformation symmetry or the dimensional fabric. Syntectonic recrystallization of ice throughout the glacier tongue characteristically produces a strong single-maximum fabric, the orientation of which in relation to the stress field is apparently determined by stress level. Under steady-state conditions of flow, the strength of the maximum also appears to be a function of stress level.
\end{abstract}

RÉsumé. Structure et pétrographie de la glace dans le Meserve Glacier, Antarctique. On rend compte des résultats d'analyses pétrographiques et structurelles de glace froide à grains fins, issue de la langue du Meserve Glacier, dans l'Antarctique. La plus grande part de la glace basale est remarquablement uniforme dans sa texture et montre une orientation d'axe optique avec un seul et important maximum, ce qui corrobore l'hypothèse de conditions stables d'écoulement. A moins de $0,5 \mathrm{~m}$ de l'interface glace-roche, les irrégularités du lit entrainent des perturbations qui sont liées à une recristallisation et à des changements dans la structure de la glace. Les orientations d'axes optiques dans la glace basale, montrent d'étroites relations de symétrie avec la structure dimensionelle et la symétrie de déformation. Le grain de glace s'accroît en allant vers la surface du glacier et le maximum unique de la direction des axes optiques subit une rotation autour du vecteur écoulement. Près de la surface où les vitesses de déformation sont relativement beaucoup moindres, la symétrie des orientations d'axes optiques n'est plus étroitement liée soit à la symétrie de déformation, soit à la structure dimensionelle. La recristallisation syntectonique de la glace à l'intérieur de la langue du glacier produit de manière caractérisée un important maximum unique d'orientation structurelle, dont la direction en relation avec le champ de contrainte est apparemment déterminée par le niveau de contrainte. Dans des conditions stables d'écoulement, l'intensité du maximum semble être une fonction du niveau des contraintes.

Zusammenfassung. Eisstruktur und -petrographie am Meserve Glacier, Antarktika. Es werden Ergebnisse petrographischer und struktureller Analysen von feinkörnigem, kaltem Eis aus der Zunge des Meserve Glacier, Antarktika, beschrieben. Der grösste Teil des Eises am Untergrund hat eine bemerkenswert einheitliche Textur und zeigt in der Anordnung der optischen Achsen ein einziges kräftiges Maximum, was mit dem Zustand stationären Fliessens übereinstimmt. Unregelmässigkeiten des Bettes verursachen innerhalb von $0,5 \mathrm{~m}$ der Eis-Fels-Grenzschicht Fliessstörungen, die mit Rekristallisation und Veränderungen der Struktur des Eises verbunden sind. Die Anordnung der optischen Achsen im Eis am Untergrund steht mit ihren Symmetrie-eigenschaften in enger Beziehung zur räumlichen Struktur und zur Symmetrie der Verformung. Die Korngrösse des Eises nimmt zur Gletscheroberfläche hin zu, wobei das Maximum in der Anordnung der optischen Achsen eine Drehung um den Fliessvektor erfährt. Nahe der Oberfläche, wo die Verformungsgeschwindigkeiten relativ viel niedriger sind, steht die Symmetrie in der Anordnung der optischen Achsen weder mit der Verformungssymmetrie noch mit der räumlichen Struktur in engerer Beziehung. Syntektonische Rekristallisation von Eis innerhalb der gesamten Gletscherzunge erzeugt charakteristischerweise eine Struktur mit einem kräftigen Einzelmaximum, deren Orientierung zum Spannungsfeld offenbar vom Spannungsniveau bestimmt wird. Bei stationären Fliessverhältnissen scheint die Grösse des Maximums ebenfalls eine Funktion des Spannungsniveaus zu sein.

\section{INTRODUGTION}

Meserve Glacier is a small "alpine" glacier located on the south side of Wright Valley in the "Dry Valleys" area of southern Victoria Land, Antarctica. Since 1965, this cold glacier has been the subject of a number of studies concerned with ice physics (Holdsworth, I969, unpublished; Holdsworth and Bull, r970) and mass balance (Bull and Carnein, 1970). The purpose of this paper is to present the results of petrographic and fabric studies of ice samples

* Contribution No. 256 of the Institute of Polar Studies, Ohio State University, Columbus, Ohio 43210 , U.S.A.

$\dagger$ Current affiliation: Hydrological Survey, Water and Soil Division, Ministry of Works, Christchurch, New Zealand. 

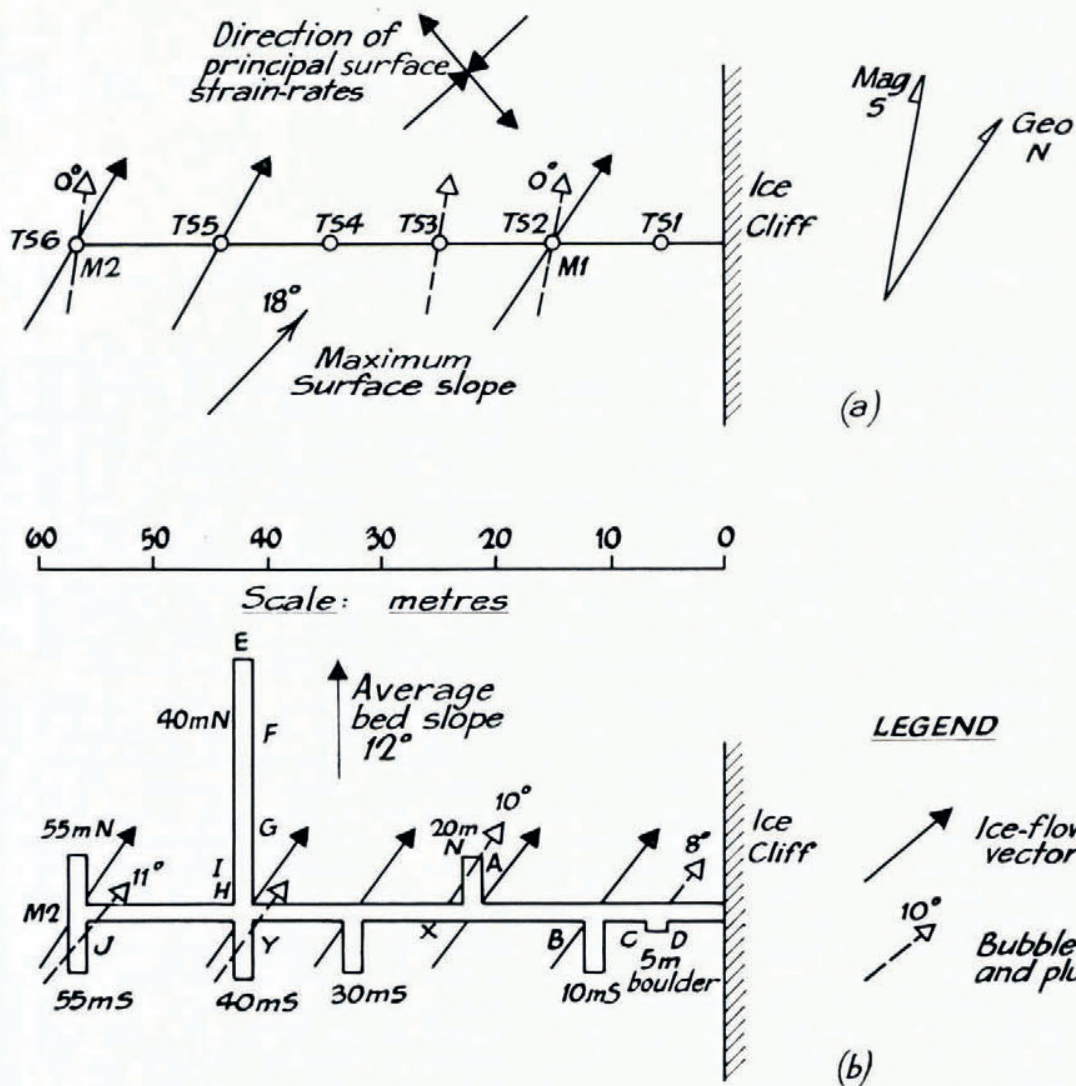

LEGEND

(a)

\section{LEGEND}

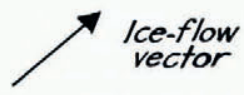

$10^{\circ}$

Bubble lineation and plunge

(b)
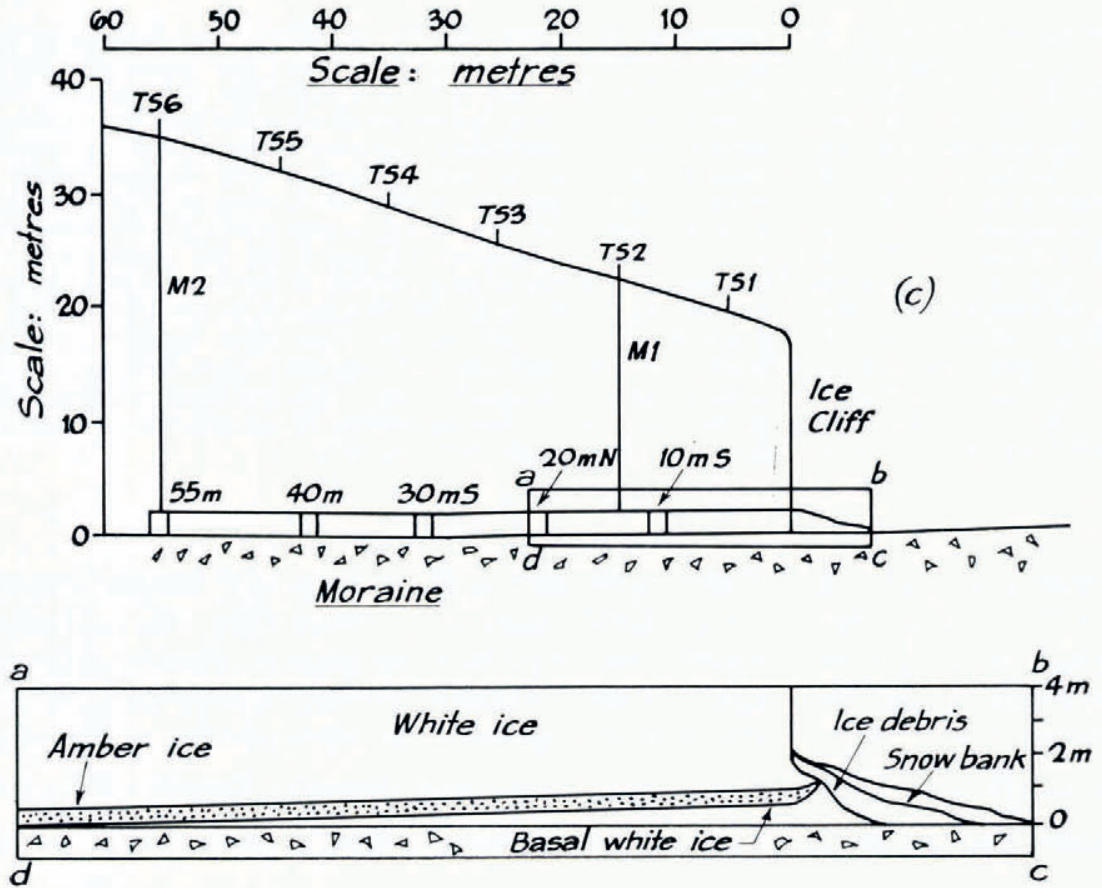

Fig. I. 
collected from the tongue of Meserve Glacier in conjunction with the investigations of ice flow. Some preliminary findings have been reported by Holdsworth (unpublished), and Holdsworth and Bull (1970).

\section{SAMPLING SITES}

The tongue of Meserve Glacier is about $600 \mathrm{~m}$ wide and extends for $2 \mathrm{~km}$ down the valley wall with an average slope of about $12^{\circ}$. It is not significantly incised into the valley wall, and terminates in a cliff about $20 \mathrm{~m}$ high. Full descriptions of the glacier have been given in the earlier publications.

Most of the ice samples were taken from a tunnel excavated during the r $965-66$ field season at the base of the glacier, roughly perpendicular to the eastern cliffed margin about $400 \mathrm{~m}$ from the glacier terminus (Fig. I). Sample blocks were cut from the tunnel walls by chain saw. Samples were also obtained from two locations at the glacier surface above the tunnel. During the $1966-67$ season, ice samples were recovered from a vertical bore hole (M2) drilled from the surface to the tunnel. Sampling sites are shown in Figure $\mathrm{I}$ and a list of samples is given in Table I.

TAble I. Summary of ICE-Sample data

\begin{tabular}{|c|c|c|c|c|c|}
\hline $\begin{array}{l}\text { Sample } \\
\text { number }\end{array}$ & $\begin{array}{l}\text { Locality } \\
(\text { Fig. Ib })\end{array}$ & $\begin{array}{l}\text { Thin } \\
\text { section }\end{array}$ & Replica & Fabric type & $\begin{array}{c}\text { Average } \\
\text { grain } \\
\text { area } \\
\mathrm{mm}^{2}\end{array}$ \\
\hline \multicolumn{6}{|c|}{ White ice below amber layer } \\
\hline $\mathrm{A}_{3.1}$ & A & $3 \mathrm{H}$ & - & I max. + girdle & 一 \\
\hline A3. I & A & $4 \mathrm{H}$ & 一 & I $\max$. & - \\
\hline $\mathrm{B}_{2.2}$ & B & IV & - & - & 一 \\
\hline $\mathrm{B}_{4}$ & B & $\mathrm{B}_{4}$ & - & I max. + girdle & 一 \\
\hline $\mathrm{C}_{2}$ & C & a & - & 2 max. + girdle & 一 \\
\hline $\mathrm{C}_{2}$ & C & b & - & - & - \\
\hline Y & $\mathrm{Y}$ & IV & - & girdle & - \\
\hline \multicolumn{6}{|c|}{ Amber ice } \\
\hline $\mathrm{A}_{3.2}$ & A & $2 \mathrm{~V}$ & - & I $\max$. & - \\
\hline $\mathrm{C}_{\mathrm{I}}$ & C & $a, b$ & - & - & - \\
\hline $\mathrm{D}_{3}$ & D & $\mathrm{D}_{3}$ & $\mathrm{D}_{3}$ & 一 & o. 15 \\
\hline $\mathrm{Hr}$ & $\mathrm{H}$ & $\mathrm{a}, \mathrm{b}$ & - & - & - \\
\hline $\mathrm{J} 3$ & $\mathrm{~J}$ & $\bar{v}$ & J3 & - & - \\
\hline $\mathrm{x}$ & $\mathrm{X}$ & IV & - & - & - \\
\hline $\mathrm{X}$ & $\mathrm{X}$ & $2 \mathrm{~V}$ & 一 & I max. + girdle & 一 \\
\hline \multicolumn{6}{|c|}{ White ice above amber layer } \\
\hline AI.I & A & $3 \mathrm{~V}$ & - & $I \max$. & - \\
\hline $\mathrm{A}_{4.1}$ & A & $4 \mathrm{~V}$ & - & I $\max$. & - \\
\hline $\mathrm{B} 9$ & B & B9 & B9 & $1 \max$ & 2.2 \\
\hline $\mathrm{D}_{4}$ & D & $\mathrm{D}_{4}$ & $\mathrm{D}_{4}$ & - & - \\
\hline $\mathrm{E}_{2}$ & $\mathrm{E}$ & $\mathrm{E}_{2}$ & - & - & - \\
\hline $\mathrm{E}_{7}$ & $\mathrm{E}$ & $\mathrm{E}_{7}$ & - & - & - \\
\hline $\mathrm{F}_{2}$ & $\mathrm{~F}$ & $\mathrm{~F}_{2}$ & - & I $\max$. & - \\
\hline $\mathrm{G}_{3}$ & G & $\mathrm{G}_{3}$ & - & - & - \\
\hline $\mathrm{H}_{5}$ & $\mathrm{H}$ & $\mathrm{H}_{5}$ & - & I $\max$ & - \\
\hline 5 & $\mathrm{M} 2$ & 5 & 一 & I max. + girdle & 6.8 \\
\hline 7 & $\mathrm{M} 2$ & 7 & - & I max. + girdle & 7.1 \\
\hline I3 & $\mathrm{M} 2$ & 13 & - & I $\max$ & 6.2 \\
\hline 17 & $\mathrm{M} 2$ & 17 & - & I $\max$. & $4 \cdot 3$ \\
\hline 20. I & $\mathrm{M}_{2}$ & 20. I & 一 & I $\max$. & 3.8 \\
\hline 25.1 & $\mathrm{M}_{2}$ & 25.1 & 一 & I $\max$. & $3 \cdot 3$ \\
\hline $\mathrm{TS}_{3}$ & $\mathrm{TS}_{3}$ & $9 \overline{\mathrm{H}}$ & 一 & I max. + girdle & - \\
\hline TS6 & TS6 & TS6 & - & - & - \\
\hline
\end{tabular}

Fig. I. (a) Plan of surface stakes above tunnel showing orientations of bubble lineation, flow vectors and principal strain-rates. (b) Plan of tunnel showing sampling locations and orientations of bubble lineation and flow vectors. (c) Vertical section along centre line of tunnel. Inset abcd shows the basal amber layer and the underlying wedge of white ice. 


\section{STructure AND Flow}

Full structural descriptions and analysis of the flow of Meserve Glacier in the vicinity of the tunnel have been given by Holdsworth (unpublished) and Holdsworth and Bull (1970).

The bed of the glacier, as observed in the tunnel, comprises ice-cemented rock debris, including boulders projecting as much as $0.3 \mathrm{~m}$ above the general level of the bed. Near the tunnel entrance, a wedge of white bubbly ice was observed at the base of the glacier. This layer is about $0.4 \mathrm{~m}$ thick at the glacier edge, where it merges with an apron of accumulated ice debris and snow at the foot of the cliff, and it wedges out about $20 \mathrm{~m}$ in from the cliff (Fig. Ic). The origin of this layer is attributed to over-riding and assimilation of the snow and ice apron during an advance of the cliff. Overlying this wedge of white ice, and forming the basal layer of the glacier elsewhere in the tunnel, is a layer of amber-coloured bubbly ice varying from 0.4 to $0.6 \mathrm{~m}$ in thickness. This amber ice contains high concentrations of salts and insoluble rock debris, and the distribution of macroscopic debris within the layer is remarkably uniform. Above the amber layer, white bubbly ice containing very little debris forms the bulk of the glacier tongue.

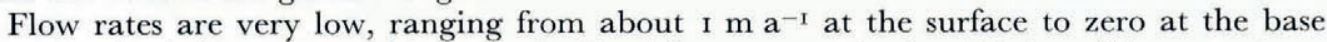
where the ice is in contact with the bed. Basal flow vectors in the vicinity of the tunnel are orientated parallel to the bed of the glacier at about $40^{\circ}$ to the glacier margin (Fig. Ib). Measurements indicate that the plasticity of the amber ice is much greater than that of the white ice. Surface flow vectors are approximately horizontal and orientated at $33^{\circ}$ to the slacier edge. The azimuth of the flow vectors is assumed to vary linearly between the bed and the surface.

At the base of the glacier the flow vectors are coincident with the direction of maximum shearing strain-rate which is parallel to the ice-rock interface. Trajectories of principal strain-rates (averaged over distances of $\mathrm{I} \mathrm{m}$ ) in the plane of the glacier bed are assumed to be parallel to and perpendicular to the flow lines. At the surface, however, the measured trajectories of principal strain-rates (averaged over distances of $200 \mathrm{~m}$ ) diverge from the flow lines (Fig. Ia). Well-developed bubble lineation occurs parallel to the flow vectors at the base of the glacier, whereas at the surface a weaker bubble lineation occurs parallel to the longitudinal axis of the tongue at an angle of $23^{\circ}$ to the flow vectors.

Cavities were observed on the down-glacier side of large boulders projecting above the glacier bed. These cavities contain well-developed sublimation crystals of ice and in the larger cavities masses of almost bubble-free stagnant ice are often found adhering to the lower part of the boulder and the floor of the cavity. The stagnant ice is probably "fossil" congelation ice preserved by advance of the glacier tongue.

\section{Petrographic anAlysis}

Thin sections of ice samples were prepared in the field and at McMurdo Station during the $1965-66$ season. The sections were cut by band saw and then ground by hand to a thickness of about $0.5 \mathrm{~mm}$ for examination between crossed polaroids on a Rigsby stage. Some of the samples were returned to the Ohio State University for further investigation. Samples from the bore hole drilled in I966-67 were also returned for analysis. These latter samples were not examined until early I 969 and may have undergone changes in grain texture during storage. However, the samples collected in $1965^{-66}$ showed no significant change during their longer period in storage.

Considerable difficulty was experienced in preparing thin sections of debris-rich amber ice. Consequently, some samples were studied by replica techniques. The plastic (formvar) replicas of thermally etched surfaces were studied under a microscope, which permitted detailed observation of grain texture. Formvar replicas taken from the coarser-grained 
white ice also proved useful for grain-size analysis. However, this phase of the studies was not completed.

\section{Petrography of the basal ice}

White ice above the amber layer. Above the amber layer and extending up to a height of $6.5 \mathrm{~m}$ above the glacier bed, the basal ice encountered in the tunnel appeared to be remarkably uniform in composition. This ice contains abundant small bubbles, most of which are needle-shaped (up to $5 \mathrm{~mm}$ in length) and aligned parallel to the measured flow direction, producing a well-defined lineation structure. A weak foliation structure defined by subtle variations in bubble content was observed in the tunnel walls, but it could not be detected in the hand specimen or thin section. The foliation layers are parallel to the plane of the glacier bed.

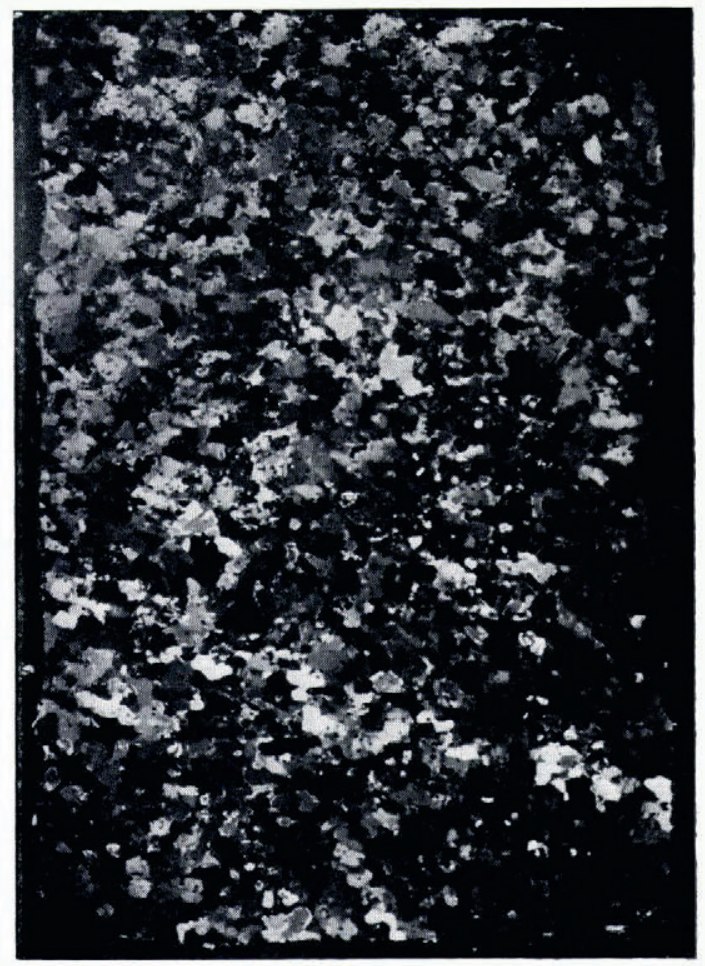

Fig. 2. Thin section of t)pical white bubbly ice. For scale see Figure II. (Section B9, between crossed polaroids.)

The ice is uniformly fine-grained, as seen in thin section (Fig. 2) and on thermally etched surfaces on the tunnel walls. Most grains are about $\mathrm{I}-3 \mathrm{~mm}$ in maximum dimension and form an interlocking aggregate. Grain shapes are generally fairly equant but the larger grains tend to be more irregular. Very few grains show undulatory extinction.

A representative sample, $\mathrm{B}$, was sectioned parallel to four planes varying in orientation relative to the bubble lineation and the apparent grain-size in each plane was measured from formvar replicas. Cumulative grain-size curves, based on measurements of the long axis of each grain, are shown in Figure 3. All four curves are similar and indicate a median grainsize of about $1.5 \mathrm{~mm}$. Counts of the density of grain boundaries recorded in traverses in selected directions across each plane show a slight flattening of the grains (flattening ratio o.84-0.90) normal to the glacier bed. 
Amber ice. The amber ice contains numerous small debris particles and abundant bubbles, which are somewhat smaller than those in the overlying white ice. Most of the bubbles are needle-shaped and aligned parallel to the measured flow vector, defining a strong lineation structure. The ice is typically very fine-grained, most grains having a maximum dimension of less than I $\mathrm{mm}$ in section (Fig. 4). Without magnification, the texture appears to be cataclastic, but under the microscope the grains show simple polygonal shapes. Grains are noticeably flattened normal to the plane of the amber layer (flattening ratio about 0.7 ).

Formvar replicas were used to measure the apparent grain-size (long axis) in two mutually perpendicular planes in a representative sample, $D_{3}$. Cumulative grain-size curves derived from these measurements are shown in Figure 3 and indicate a median grain-size of $0.6 \mathrm{~mm}$. The average grain area, determined by counting the number of grains in a measured area of each replica, is $0.15 \mathrm{~mm}^{2}$.

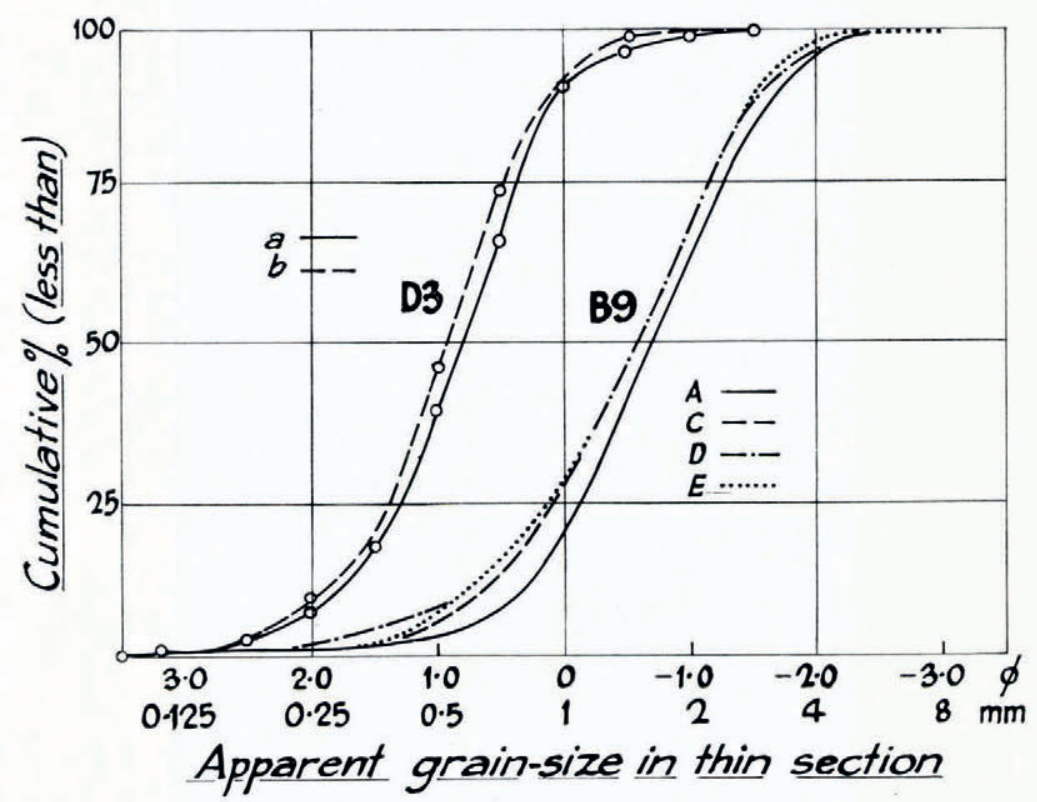

Fig. 3. Cumulative grain-size curves for samples of white ice $\left(B_{9}\right)$ and amber ice $\left(D_{3}\right)$, based on measurements of long axis in section.

Within the amber layer, lenses of debris-free ice occur. This ice contains only scattered bubbles and the bubble lineation may be absent. Grain-size is coarser than that in the overlying white ice. Grains have maximum dimensions of $2-5 \mathrm{~mm}$ in section and show an irregular interlocking texture (Figs. 4 and 5).

In some cavities at the base of the glacier, tongues of amber ice having a "ropy" appearance have been extruded into the opening. Samples were taken from a tongue of "ropy" ice which had been forced round the side of a boulder at locality $\mathrm{X}$. This ice contained less debris than the typical amber ice and contained numerous highly elongated bubbles which were strongly aligned parallel to the direction of extrusion. Grain-size was greater than in the typical amber ice, the grains having maximum dimensions of $\mathrm{I}-3 \mathrm{~mm}$, and the texture was similar to that of the overlying white ice. 


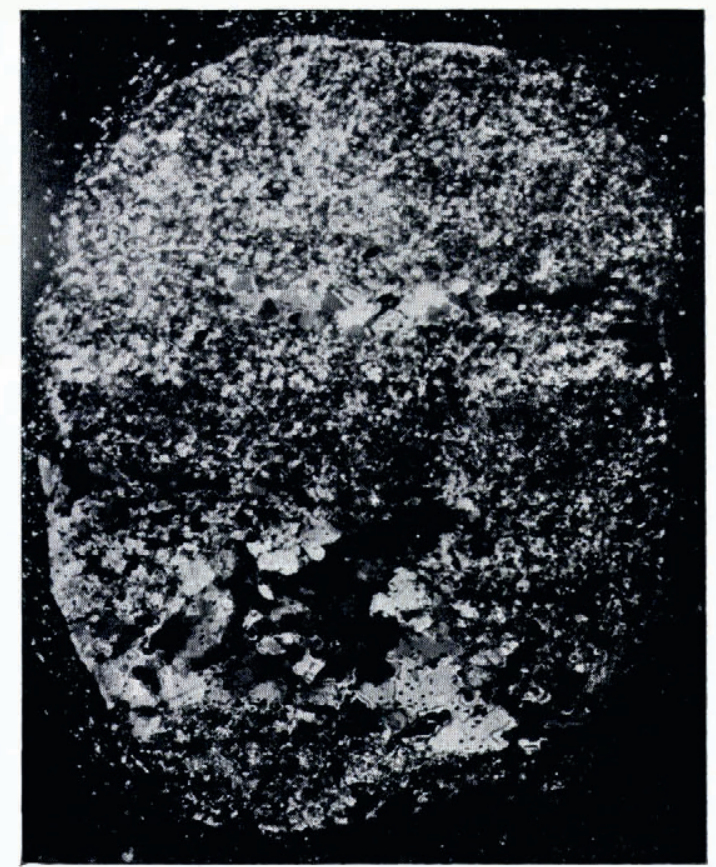

Fig. 4. Thin section of typical amber ice showing coarser-grained clear layers. For scale see Figure II. (Section $A_{3} .2 V_{2}$, between crossed polaroids.)

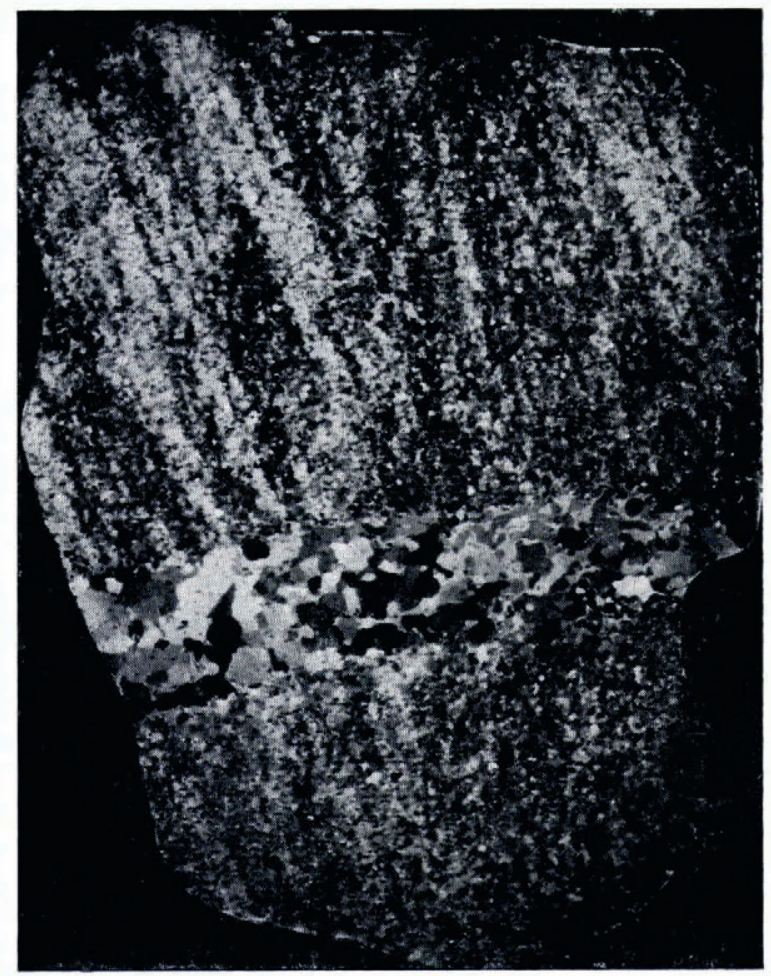

Fig. 5. Thin section of amber ice showing well-developed fabric domains and a sharply defined clear layer at the base. For scale see Figure 11. (Section Crb, between crossed polaroids.) 
White ice below the amber layer. Where the geometry of flow is simple and the ice flows over a planar rock surface, the basal white ice below the amber layer is similar in grain-size, texture and bubble content to the white ice above the amber ice. In one section, $\mathrm{B}_{4}$, which extended to the rock-ice interface, grains less than $\mathrm{I} \mathrm{mm}$ in size occurred at the interface (Fig. 6).

Where the flow of this basal ice is disturbed by irregularities in the glacier bed, the ice shows variations both in bubble content and grain-size, and undulatory extinction was observed more frequently in thin sections. On the up-glacier side of a large boulder $5 \mathrm{~m}$

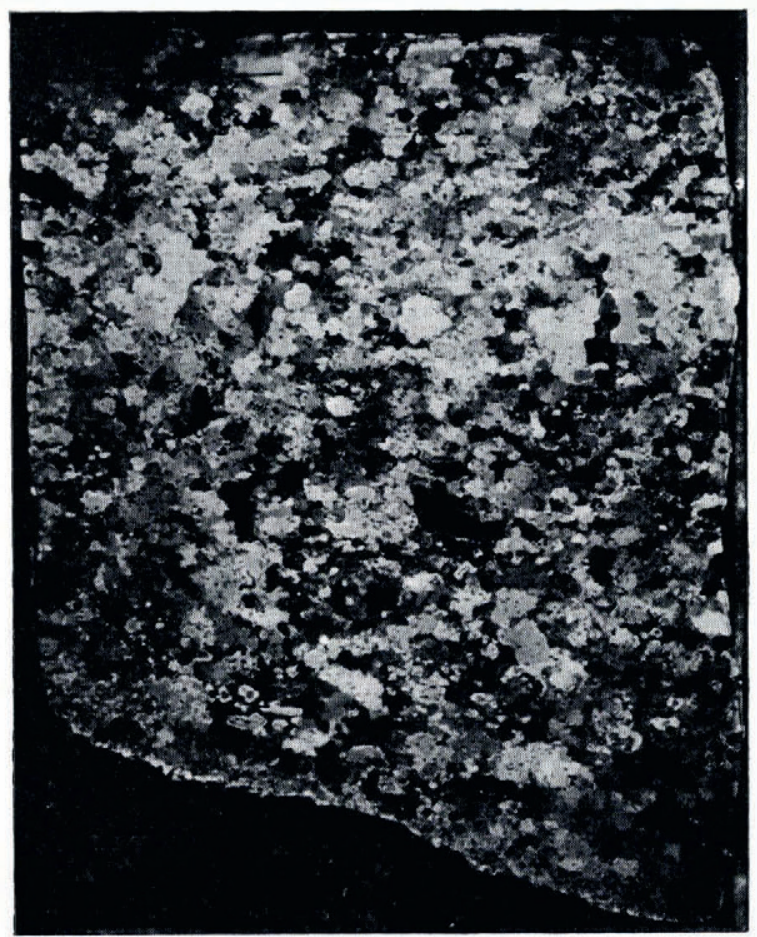

Fig. 6. Thin section of basal white ice. Bottom of section marks the rock-ice interface. Centimetre scale at top left. (Section $B_{4}$, between crossed polaroids.)

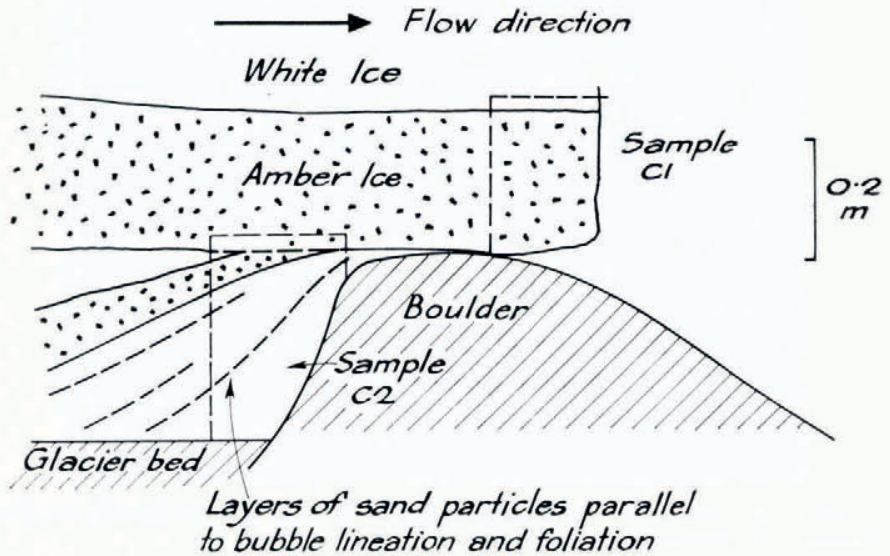

Fig. 7. Vertical section across $5 \mathrm{~m}$ boulder, approximately parallel to direction of ice flow, showing location of samples $C_{I}$ and $C_{2}$. 
from the tunnel entrance, basal white ice showed steeply dipping bubble lineation and foliation defined by layers of bubbly and clear ice (Fig. 7). Ice immediately adjacent to the boulder was almost bubble-free and relatively coarse-grained (maximum grain dimensions up to Io $\mathrm{mm}$ ) and showed an irregular interlocking texture (Fig. 8). Down-glacier from small rock steps at localities A and B (Fig. Ib), well-defined layers of bubbly and clear ice were also observed. The clear ice was coarser-grained than the bubbly ice and showed a more irregular interlocking texture (Fig. 9).

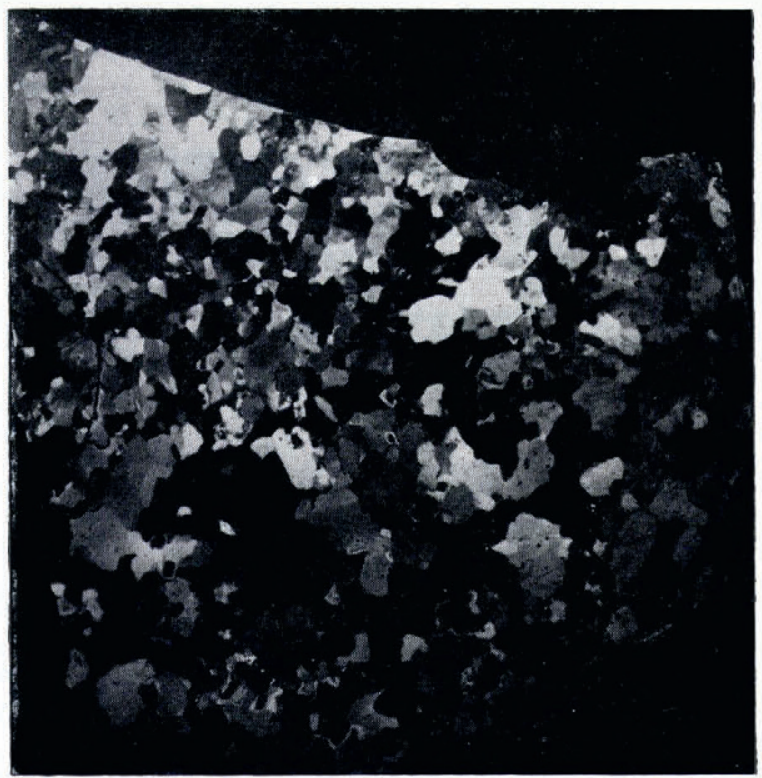

Fig. 8. Thin section of basal white ice cut parallel to the up-glacier face of the $5 \mathrm{~m}$ boulder, showing coarser grain-size and irregular interlocking texture. Centimetre scale at tottom. (Section C2a, between crossed polaroids.)

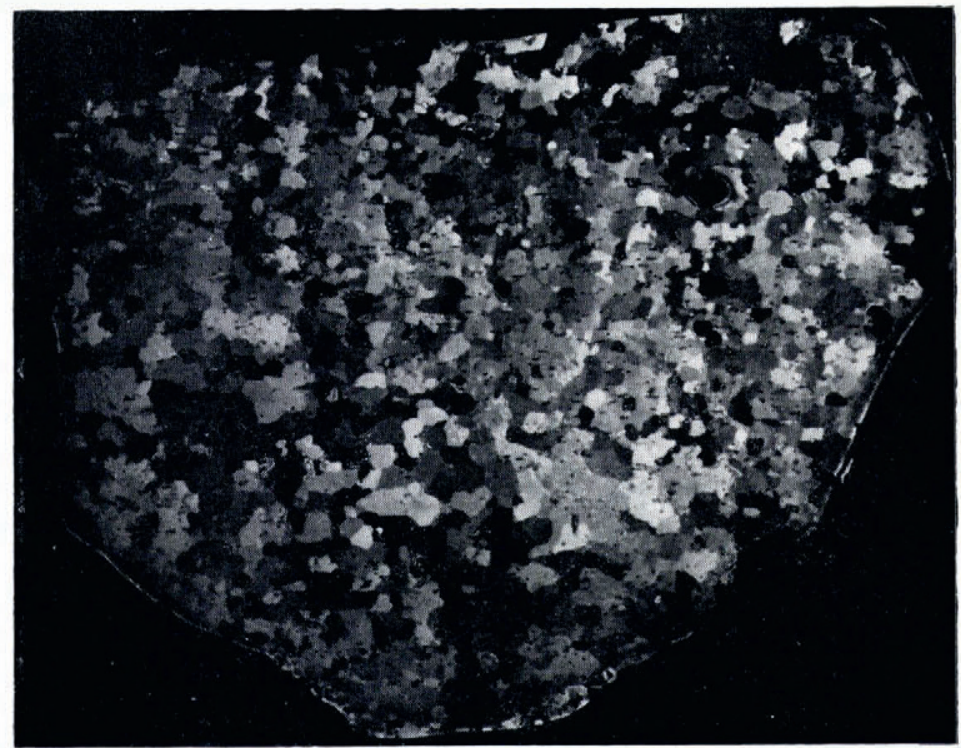

Fig. 9. Thin section of basal white ice cut parallel to the flow direction down-glacier from a rock step in the glacier bed, showing coarser grain-size associated with clear layers. For scale see Figure II. (Section B2.2 IV, between crossed polaroids.) 
A sample of stagnant ice from a cavity at locality $\mathrm{Y}$ was relatively coarse-grained and showed simple polygonal grain shapes unlike those in the actively deforming ice (Fig. Io).

\section{Petrography of ice above the tunnel}

Ice cores were recovered from bore hole $\mathrm{M}_{2}$ which penetrated the glacier from the surface, approximately $35 \mathrm{~m}$ above the bed, to the tunnel. Up to a height of about $20 \mathrm{~m}$ above the bed, the ice appears to be similar to the ice above the amber layer in the tunnel (Fig. II). Measurements of average grain area in the thin sections indicate a gradual increase in grainsize with height above the glacier bed.

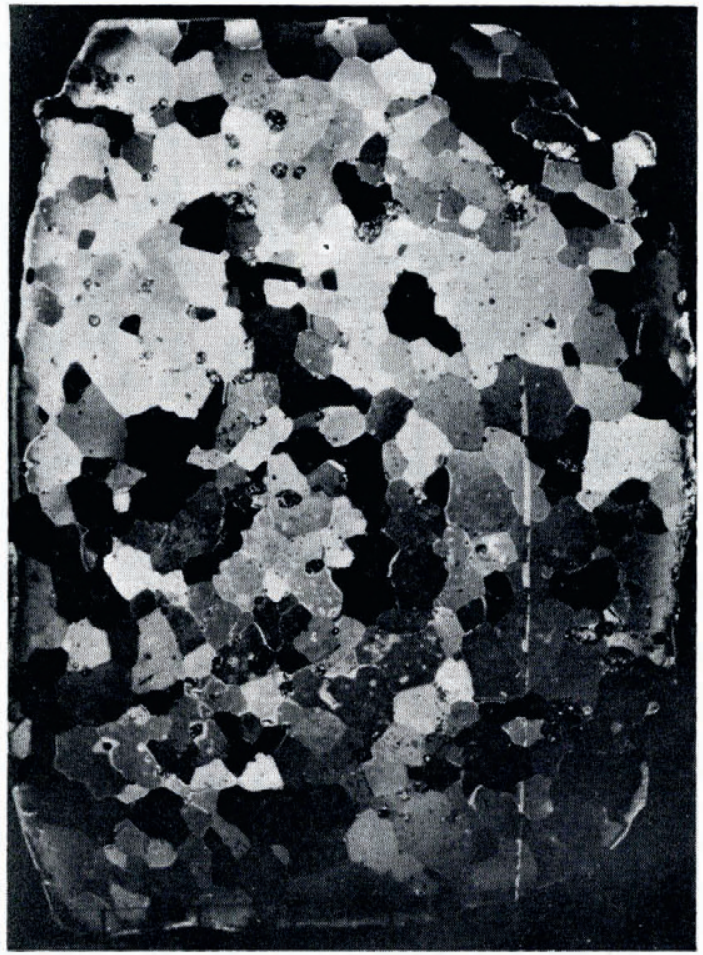

Fig. Io. Thin section of stagnant ice from the base of a cavity. Centimetre scale at bottom. (Section $r$, between crossed polaroids.)

Grain-size increases significantly in the upper $15 \mathrm{~m}$ of the glacier. Most grains have maximum dimensions of $2-6 \mathrm{~mm}$ in section and show an interlocking texture (Fig. 12). Bubble content is lower and the bubble lineation is weaker in the near-surface ice. The bubble lineation is orientated at $23^{\circ}$ to the flow direction and is presumably a relict structure, derived from the "ice fall" at the head of the glacier tongue.

The variation of grain-size from top to bottom of the glacier is shown in Figure 13 . Above the amber layer grain-size increases approximately linearly to $18 \mathrm{~m}$ above the bed. Between $\mathrm{I} 8$ and $23 \mathrm{~m}$ above the bed there is a discontinuity in the curve and above $23 \mathrm{~m}$ the grain-size is distinctly coarser. Sampling of the near-surface ice is insufficient to confirm the grain-size trend suggested in the diagram. 


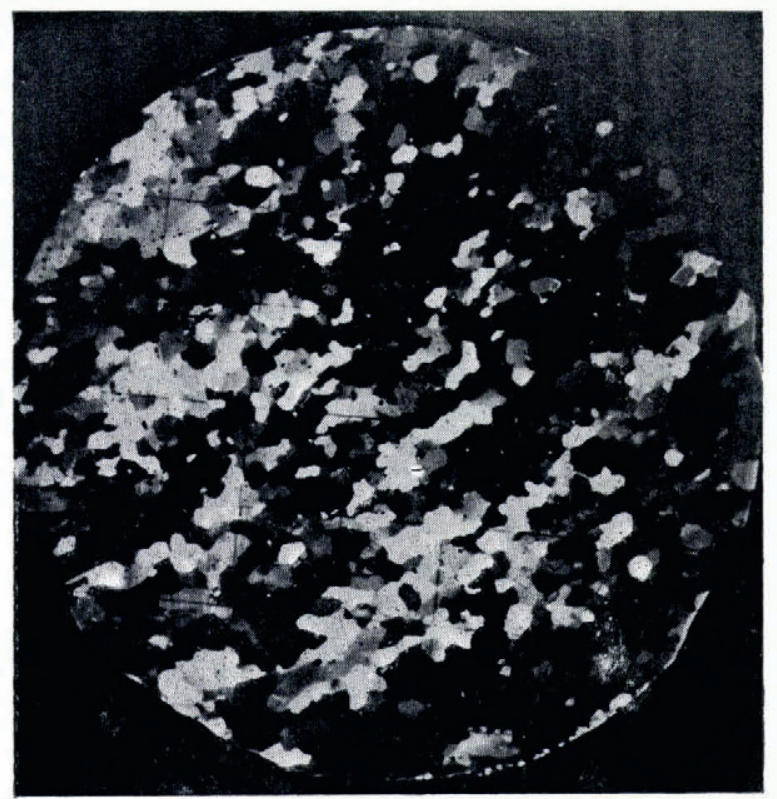

Fig. 11 . Thin section of ice from $13 \mathrm{~m}$ above the glacier bed showing weakly developed fabric domains. Centimetre grid superimposed. (Section M2 20.I, between crossed polaroids.)

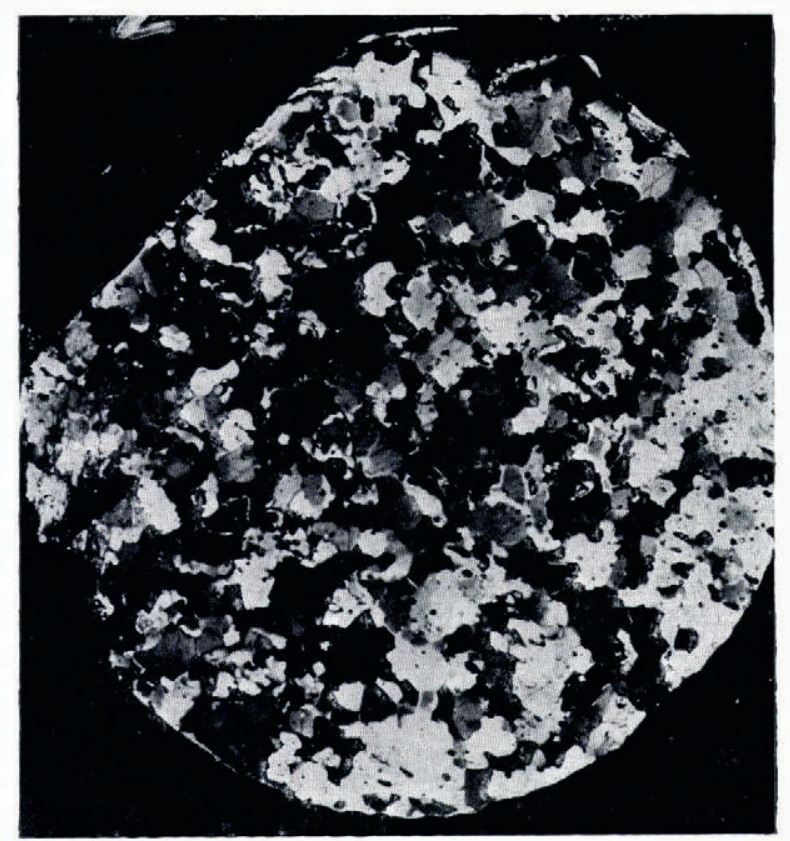

Fig. 12. Thin section of ice from the upper surface of the glacier tongue. Centimetre scale at top. (Section TS $9 \mathrm{SH}_{\mathrm{g}}$ between crossed polaroids.) 


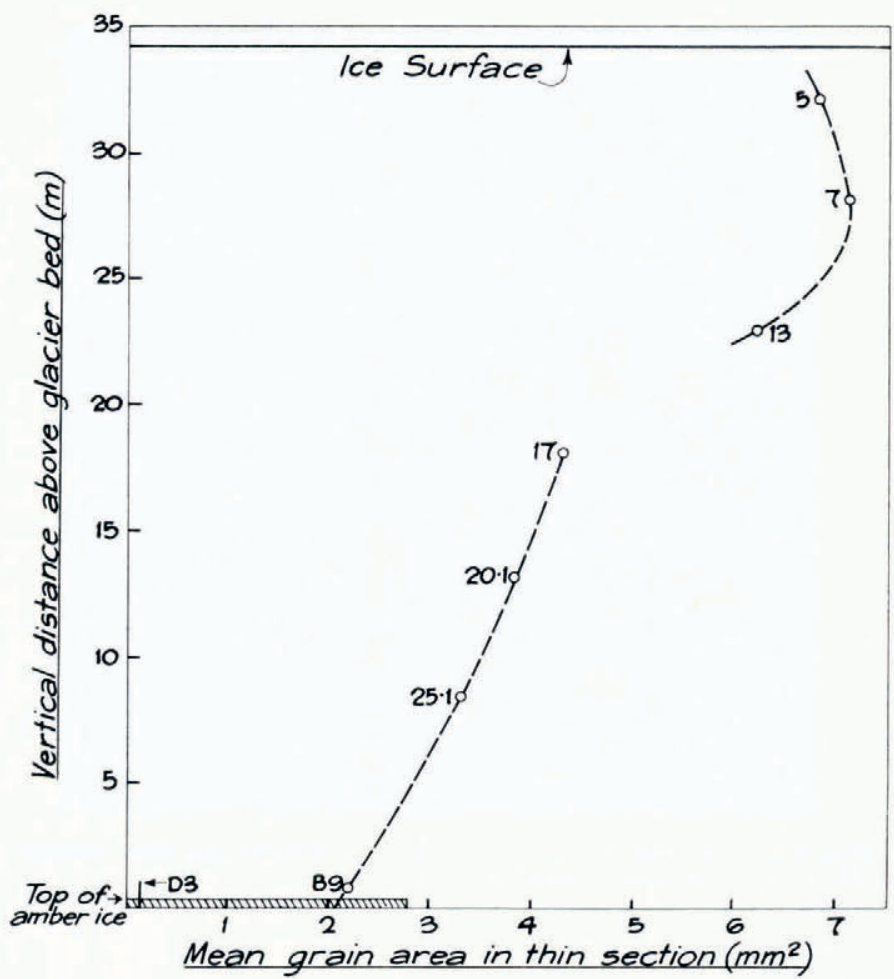

Fig. 13. Variation in grain-size of ice from base of glacier to surface as shown by measurements of average grain area in thin section.

\section{ICE FABRICS}

The term "ice fabric" refers primarily to the preferred orientation of crystallographic fabric elements ( $a$-axes and optic or $c$-axes) in ice, but should also include the preferred orientation of dimensional elements such as bubbles.

Optic-axis orientations were measured in thin sections on a Rigsby universal stage. Some difficulty was experienced in measuring the orientations of crystals in the fine-grained samples and the very fine-grained samples of amber ice could not be analysed by this method. Attempts were made to measure the crystal orientations in thin sections of amber ice using a standard petrographic microscope and universal stage, but the debris content of the ice prevented preparation of satisfactory thin sections.

As an alternative to thin sections, formvar replicas were prepared with the aim of using etch pits to determine $c$-axis orientations in amber ice. The techniques used have been described by Aufdermaur and others (I963). Suitably developed etch pits proved difficult to produce in this type of ice, however, and no satisfactory measurements were obtained. Well-formed etch pits were observed in some replicas of white ice and were used to determine $a$-axis orientations.

The orientations of optic axes were measured in 20 thin sections of ice. Approximately Ioo crystals were measured in each thin section and the optic-axis orientations were plotted on equal-area diagrams. These point diagrams were contoured using a $\mathrm{I} \%$ counting circle. Most of the fabric patterns show such a high degree of preferred orientation that statistical tests of significance are considered unnecessary. 
Only the gross features and symmetry of the fabric patterns have been used in interpretation of the diagrams. Strong discrete maxima having point concentrations greater than $10 \%$ per $1 \%$ area are assumed to be real, especially where they recur in different samples. The symmetry of the optic-axis fabrics is described in terms of symmetry planes, $m$ and axes of symmetry $\infty$-fold and 2 -fold (Turner and Weiss, I963, p. 44, 64-67). Fabric patterns can be classified as axial if they show a single $\infty$-fold axis of symmetry, orthorhombic if they show three mutually perpendicular planes of symmetry, monoclinic if they show a single symmetry plane, and triclinic if no symmetry planes are present. Non-crystallographic or dimensional fabrics are described in terms of mutually perpendicular geometric axes, $a, b$ and $c$ (Turner and Weiss, I963, p. 86-9o). Where a planar structure, $S$, is present, $S$ defines the $a b$ plane and $c$ is the pole to $S$. Where a lineation occurs it defines $b$.

In the fabric diagrams, the optic-axis and dimensional fabric symmetries are indicated, together with the flow vector and, where applicable, the orientation of the principal strainrates. Most of the diagrams representing samples of ice from the tunnel have been rotated so that the plane of projection coincides with the plane of the glacier bed, while the diagrams representing core samples from above the tunnel are projected in the horizontal plane. An explanation of symbols used in the fabric diagrams is given in Figure 14 .

\section{Fabric patterns in the basal ice}

White ice above the amber layer. Visual inspection of thin sections between crossed polaroids is enough to reveal the strong preferred orientation of optic axes in the white ice above the amber layer. Optic axes are so strongly clustered about the pole to the plane of the glacier bed that the optical behaviour of the polycrystalline aggregate approaches that of a single crystal.

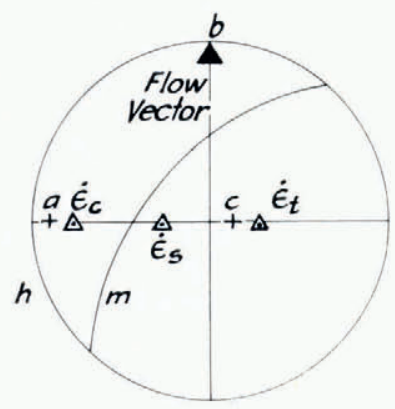

$$
\text { h_-_Horizontal plane }
$$

$$
\begin{gathered}
a, b, c \ldots \text { Symmetry axes of dimensional fabric } \\
m_{-\ldots} \text { Symmetry plane of optic axis fabric } \\
\Delta_{-} \text {Direction of principal compressive }\left(\dot{\epsilon}_{c}\right) \\
\text { tensile }\left(\dot{\epsilon}_{t}\right) \text { or shearing }\left(\dot{\epsilon}_{s}\right) \text { strain-rate } \\
\text { Contours } 1-10-20-30-40 \%
\end{gathered}
$$

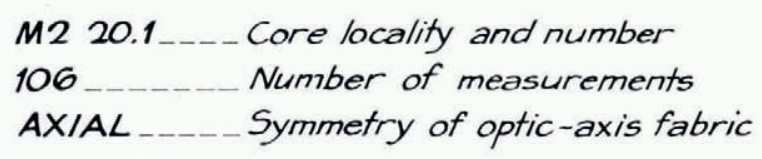

Fig. I4. Explanation of fabric diagrams. 
Short-range ordering of the fabric was frequently observed in thin section. Groups of crystals showing similar orientations tend to occur in planes approximately perpendicular to the bubble lineation. These fabric domains are best seen in thin sections cut normal to the single maximum of the fabric and are visible as bands of optically extinct crystals (Fig. I I).
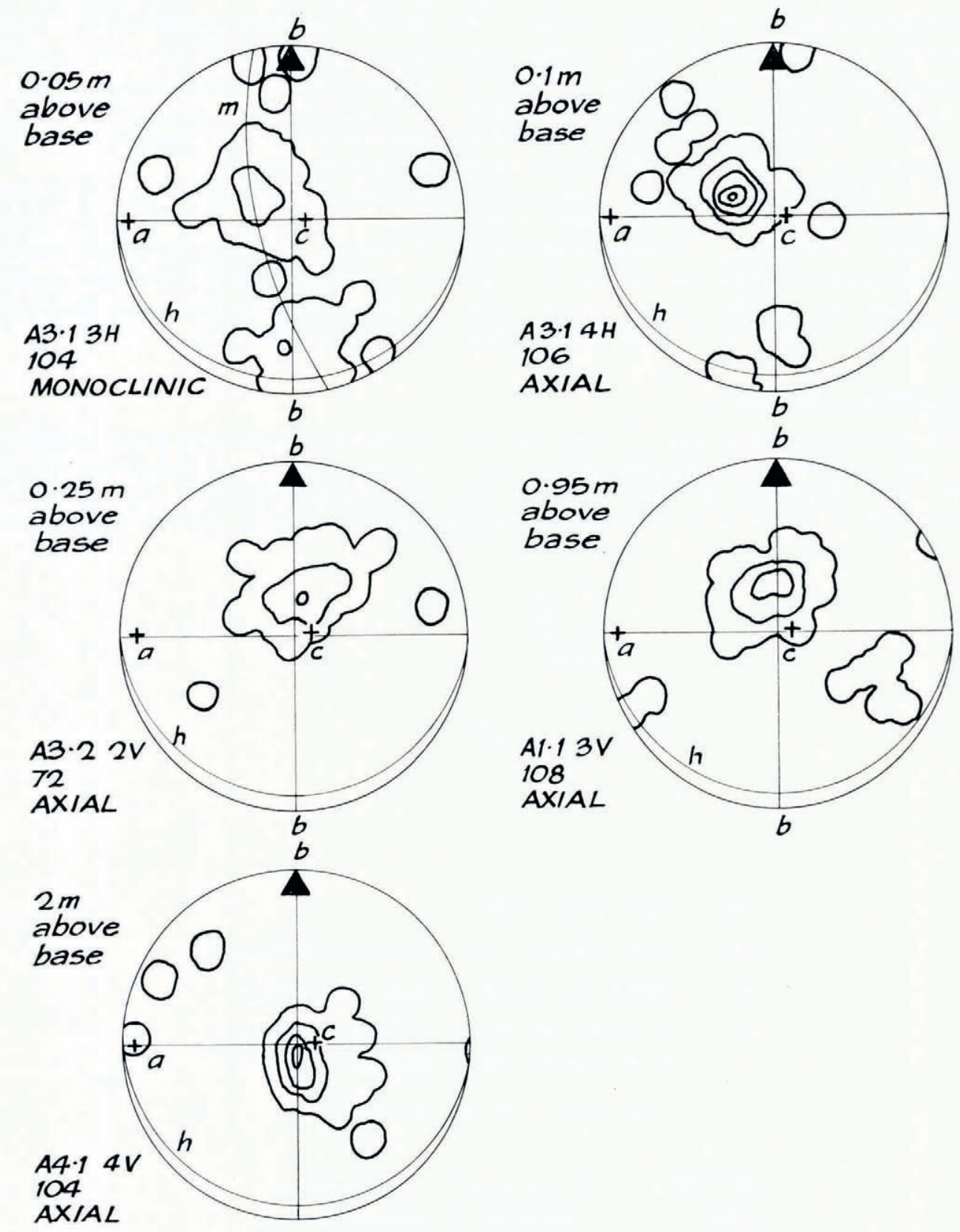

Fig. 15. Fabric diagrams of ice from tunnel locality A. Plane of projection contains flow vector and is parallel to the glacier bed. Diagrams $\mathrm{A}_{3} . \mathrm{I}{ }_{3} \mathrm{H}$ and ${ }_{4} \mathrm{H}$ represent basal white ice, diagram $\mathrm{A}_{3} .2{ }_{2} \mathrm{~V}$ represents a clear layer within the amber ice, and diagrams $A_{I . I} 3 \mathrm{~V}$ and $A_{4 . I} 4 \mathrm{~V}$ represent white ice above the amber layer. 
Measurement of optic axes from five samples showed, as expected, that the ice has a strong single-maximum fabric. In view of the optical similarity of all samples examined, further fabric measurements appeared to be unnecessary. Four samples (A4. I 4V, B9, F2 and $\mathrm{H}_{5}$ ) taken from $\mathrm{I}-4 \mathrm{~m}$ above the bed show a strong maximum with concentrations of optic axes up to $35-50 \%$ per $\mathrm{I} \%$ area of the diagram, orientated close to the pole to the glacier bed (Figs. I 5 and I $_{6}$ ). One sample, A . I $3 \mathrm{~V}$, taken from a site where flow geometry is more complex, shows a weaker $(30 \%)$ maximum orientated at an angle of $20-25^{\circ}$ to the pole to the glacier bed in the direction of flow (Fig. I5).

In order to determine whether the $a$-axis of the crystals also showed preferred orientation, etch pits in formvar replicas from sample Bg were measured. The results did not indicate any significant preferred orientation of the $a$-axes.

Amber ice. Strong preferred orientation of optic axes in the amber ice can be seen from the optical behaviour of thin sections examined between crossed polaroids. Optic-axis orientations are clustered around the pole to the glacier bed, but to a lesser degree than in the white
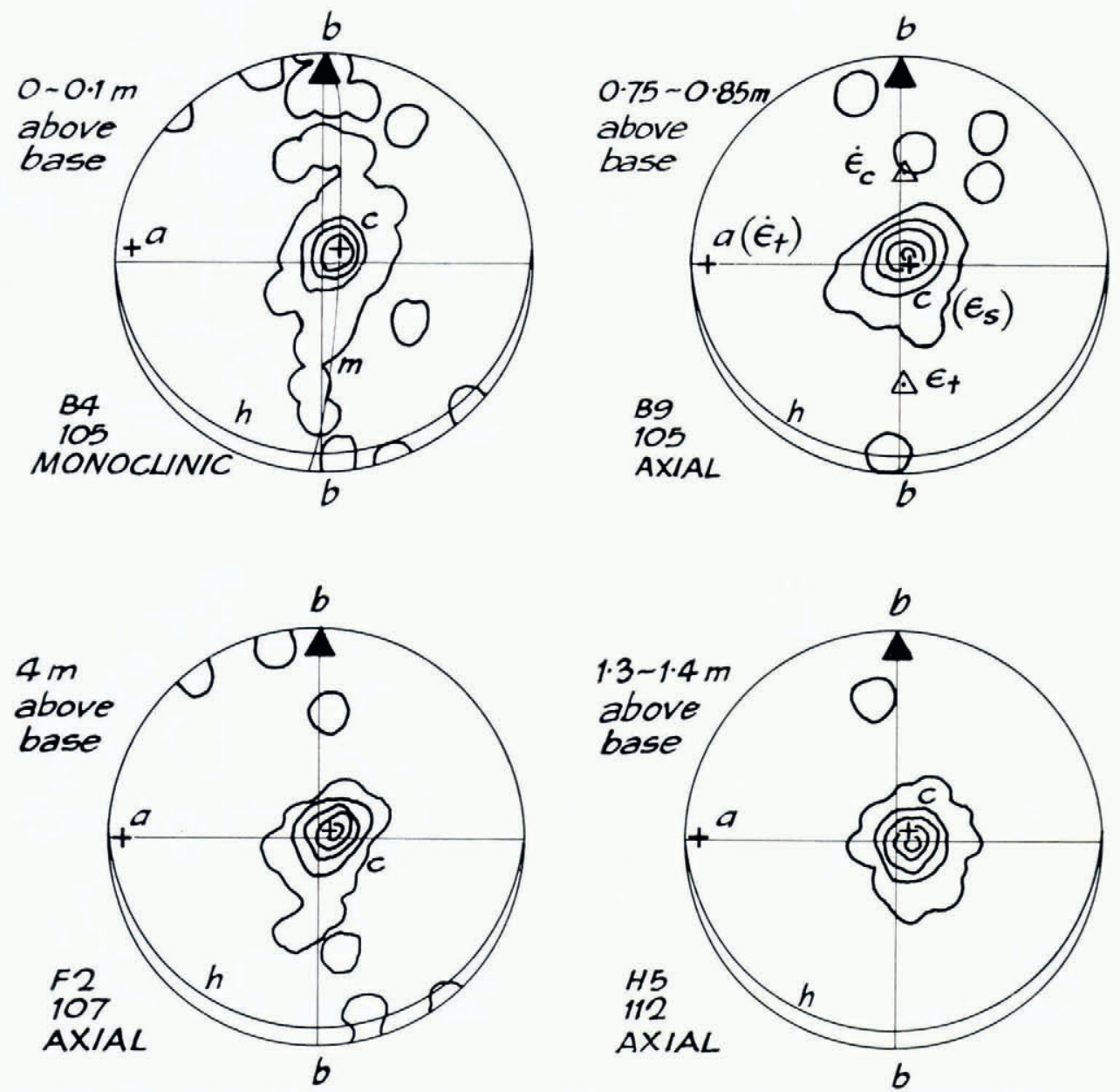

Fig. I6. Fabric diagrams of ice from tunnel localities $B, F$ and $H$. Plane of projection contains flow vector and is parallel to the glacier bed. Diagrams $\mathrm{B}_{9}, \mathrm{~F}_{2}$ and $\mathrm{H}_{5}$ represent white ice above the amber laver, and diagram $\mathrm{B}_{4}$ represents basal white ice. 
ice. No successful measurements of optic axis orientations were made in samples of amber ice. However, optic-axis orientations were measured in sample $\mathrm{A}_{3} .22 \mathrm{~V}$ in a lens of clear ice within the amber layer (Figs. 4 and I5 $_{5}$ ). The fabric shows a weak single maximum orientated similarly to the maximum recorded in sample A I. I $3 \mathrm{~V}$ representing white ice above the amber layer at this locality.

Two thin sections, Gra and Crb, were prepared from the amber layer where it flows over the large boulder, $5 \mathrm{~m}$ from the tunnel entrance (Fig. 7). These sections showed fabric domains orientated similarly to those observed in the overlying white ice but much better developed. The clear layer in section $\mathrm{C}_{\mathrm{I}}$, close to the rock-ice interface, was sharply defined and did not show the fabric domains present in the enclosing amber ice (Fig. 5). The layer probably represents a zone of concentrated shear deformation which has undergone recent recrystallization.

Optic-axis orientations were measured in a tongue of "ropy" ice from locality X (Fig. I 7). The fabric of the upper part of the tongue $\left(\mathrm{X}_{\mathrm{I}}\right)$ shows a broad single maximum centred
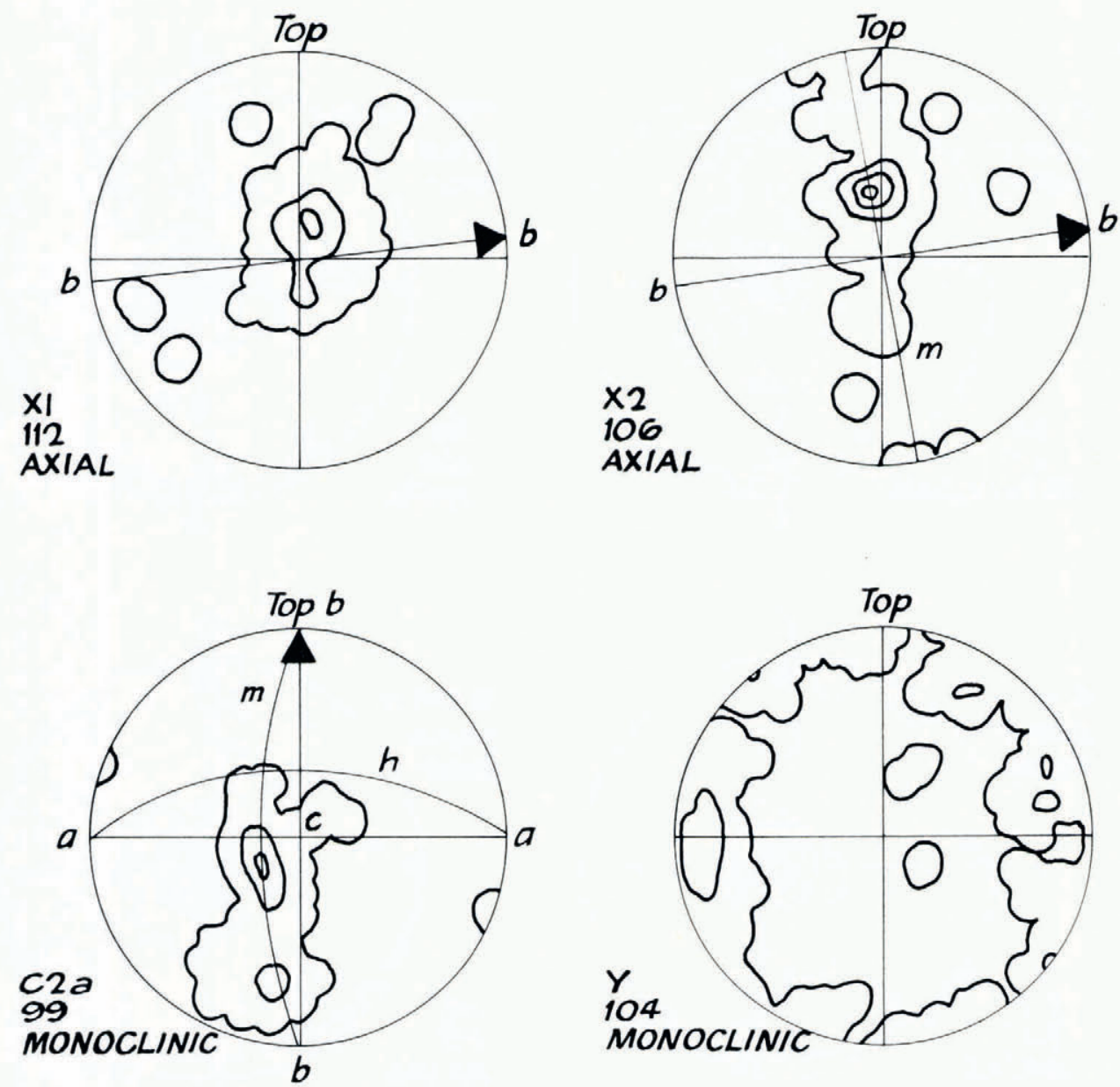

Fig. 17. Fabric diagrams of ice from tunnel localities $C, X$ and $r$. Diagrams $X_{I}$ and $X_{2}$ represent "ropy" amber ice, and plane of projection is vertical and parallel to the flow. Diagram C2a represents basal white ice and plane of projection is parallel to the up-glacier face of the $5 \mathrm{~m}$ boulder. Diagram $r$ represents stagnant ice from a cavity, and plane of projection is vertical and normal to the face of the boulder. 
approximately on the pole to the face of the boulder, while the fabric of the layer immediately adjacent to the rock $\left(\mathrm{X}_{2}\right)$ shows a similarly orientated maximum associated with a girdle about the flow direction.

White ice below the amber layer. The optic-axis fabric of sample $\mathrm{B}_{4}$ shows a strong single maximum centred on the pole to the glacier bed and a girdle parallel to the measured flow direction (Fig. I6). The symmetry of the fabric is monoclinic. The single maximum has a similar orientation to the single maximum recorded from sample B9 taken above the amber layer at the same locality.

Two samples of basal ice from locality A ( $\mathrm{A}_{3} . \mathrm{I}_{3} \mathrm{H}$ and $\left.{ }_{4} \mathrm{H}\right)$, where flow geometry is more complex, both show identically orientated single maxima about $20^{\circ}$ from the pole to the glacier bed (Fig. I 5). Section A 3 . I 3 H, taken close to the bedrock interface was coarser-grained and the fabric shows monoclinic symmetry with a girdle approximately parallel to the flow direction.

Sample C2a, cut parallel to the up-glacier face of the $5 \mathrm{~m}$ boulder shows a fabric with a partial girdle parallel to the flow direction (Figs. 4 and 17 ). Two maxima are present, one centred approximately on the pole to the glacier bed, and one centred approximately on the pole to the face of the boulder. These maxima represent two fabric domains in the section, an upper zone of finer-grained ice which appears to be forced over the top of the boulder, and a lower zone of relatively bubble-free coarser-grained ice which apparently retains the fabric maximum normal to the glacier bed (Fig. 8).

The sample of stagnant ice from a cavity at locality Y shows a very weak preferred orientation of optic axes suggesting a girdle normal to the surface of the boulder (Fig. I 7 ).

Summary. In the basal cold ice undergoing flow, strong symmetry relationships exist between optic-axis fabric, dimensional fabric, flow geometry and principal strain-rate orientations. These relationships are independent of the type of ice sampled. All optic-axis fabrics show a strong single maximum located close to the pole to the local bedrock interface which controls the flow geometry. Where foliation layering is present, the single maximum of the optic-axis fabric is approximately coincident with $c$ of the dimensional fabric. Close to the ice-rock interface, where irregularities of the bed complicate the geometry of flow, opticaxis fabrics also show girdles with planes parallel to the $b c$ plane of the dimensional fabric and to the flow vector. An optic-axis girdle normal to the flow direction was recorded in the fabric of "ropy" ice and is presumably associated with rotational flow during extrusion. Fabric domains appear to be weakly developed in the white ice throughout the tunnel and strongly developed in amber ice subjected to intense shearing deformation.

\section{Fabrics of ice above the tunnel}

Optic-axis orientations were measured in six samples from bore hole $\mathrm{M}_{2}$, and in one sample of surface ice, $\mathrm{TS}_{3}$. Visual inspection of the thin sections between crossed polaroids was sufficient to reveal a gradual weakening of preferred orientation towards the glacier surface. Fabric diagrams substantiate this trend, showing a single maximum which becomes more diffuse towards the surface (Fig. 18). The fabric patterns of samples 25. I, 20. I, I 7 and I 3 are similar to those observed in the white ice in the tunnel, while the fabrics of the uppermost samples $\left(7,5\right.$ and $\left.\mathrm{TS}_{3}\right)$ show a single maximum associated with a partial girdle. Samples 25. I, 20. I and I 7 showed the weakly developed fabric domains characteristic of the tunnel ice but these domains were absent in the upper ice.

Fabrics of the bore-hole samples show that between the bed and the surface of the glacier the single maximum undergoes a rotation of approximately $45^{\circ}$ away from the pole to the bed. Assuming that the azimuth and plunge of the flow vector vary linearly with height above the glacier bed, the observed rotation of the single maximum is equivalent to a rotation about the flow vector (Fig. I8). At the surface of the glacier, the symmetry of the optic-axis fabric is obviously related to the flow vector, but it is not simply related to either the measured principal strain-rates or to the relict bubble lineation. 


\section{Discussion}

\section{Textural relationships with deformation}

Basal ice in the vicinity of the Meserve Glacier tunnel is fine-grained throughout. The white ice is remarkably uniform in grain-size and texture, suggesting that steady-state conditions of flow prevail in the glacier tongue. The almost complete absence of undulatory extinction in the crystals can be attributed to syntectonic recrystallization during longcontinued flow.

Significant variations in grain-size occur within the ice. Samples from bore hole M2 show an increase in grain-size from the base of the glacier to the surface which is correlated with changes in shear stress and temperature regime. Experimental deformation of ice samples in the laboratory has demonstrated that grain-size after syntectonic recrystallization is controlled by stress level and by temperature (Steinemann, I958; Rigsby, I960; Kamb, I972). In these experiments, grain-size varied inversely with magnitude of the applied stress and varied directly with temperature. The approximately linear increase in grain-size of the Meserve Glacier ice up to the height of about $20 \mathrm{~m}$ above the bed is correlated with decreasing shear strain-rate and also with an approximately linear decrease in temperature. This negative temperature gradient must reduce to some extent the grain growth expected from the decrease in shear stress alone. The significantly coarser grain-size of the near-surface ice is correlated with the zone of greatest annual temperature fluctuations (Holdsworth, unpublished).

The high concentration of salts in the amber ice is probably responsible for its greater plasticity relative to the white ice (Holdsworth and Bull, 1970). Deformation of the amber ice is influenced by its extremely fine grain-size which is determined in part by the increase in shear strain-rate and in part by the inhibiting action of the uniformly distributed debris content on grain growth. Holdsworth and Bull (1970) suggested that grain-boundary creep may be involved to a significant extent in the flow of the amber ice. The small size and flattening of the grains would facilitate this process, especially if intercrystalline saline films are present. In the overlying white ice the coarser grain-size and more interlocking texture would inhibit grain-boundary creep as a deformation mechanism.

Bubble segregation and recrystallization of ice leading to grain growth occur in regions of stress concentration near irregularities in the glacier bed, affecting both the basal layer of white ice and the amber layer. Coarser grain-size is associated with development of a more highly interlocking texture, which is characteristic of ice subjected to syntectonic recrystallization and which has been produced experimentally in the laboratory (Steinemann, [1956]; $\mathrm{Kamb}, \mathrm{I}_{972}$ ). This increase in grain-size with increase in shear strain-rate appears to contradict the general inverse correlation between grain-size and stress level, but at these localities the recrystallization is not occurring under steady-state conditions and there is also a possibility that the unusually high strain-rates may lead to localized increases in temperature which would favour grain growth and also bubble migration.

\section{Ice fabrics}

A strong single maximum is characteristic of the optic-axis fabrics of the ice in the Meserve Glacier tongue. This fabric pattern has been recorded in other studies of fine-grained ice in cold glaciers (Shumskiy, I955; Goldthwait, I960; Rigsby, I960; Kizaki, I969) and in the Antarctic ice sheet (Gow, 1970). In the basal ice of Meserve Glacier the single maximum is orientated approximately normal to the plane of maximum shear stress, in this case, the

Fig. 18. Fabric diagrams of ice from above the tunnel. Plane of projection is approximately horizontal. Diagram at lower right shows the variation in position of the single maximum in relation to the flow vector. 
glacier bed, and is coincident with $c$ of the bubble foliation. Single maxima of this type are commonly orientated normal to a controlling shear plane and show that the majority of crystals in the ice are orientated so that their basal glide planes are aligned close to the plane of maximum shear stress. The crystal orientations are therefore the most favourable for plastic deformation by basal glide.

The uniformity of the single-maximum fabric in the basal white ice of Meserve Glacier suggests that steady-state conditions of flow exist in the ice. However, the presence of weakly developed fabric domains in the ice suggests that minor local departures from steady-state flow occur as the ice accommodates its flow to the irregularities of its bed. The fabric domains appear to be analogous on a much larger scale to the undulatory extinction or kink banding produced by plastic deformation of single crystals of ice. Orientation of these domains with respect to the single maximum of the highly orientated polycrystalline aggregate is similar to the orientation of extinction bands with respect to the $c$-axis of a single crystal.

Close to the ice-rock interface, irregularities in the glacier bed cause greater perturbations of flow which are reflected in the optic-axis fabric of the ice. The single maximum tends to weaken and weak girdle patterns with monoclinic symmetry are developed. The orientation of the single maximum is controlled by the local orientation of the ice-rock interface rather than by the average bed of the glacier. In the amber ice, locally increased strain-rates appear to produce fabric domains similar to those in the overlying white ice but much more strongly developed.

The optic-axis fabric patterns in the basal ice have been recorded in the typical white ice, which is a product of long-continued flow in the glacier tongue, in clear ice formed by relatively recent recrystallization in the amber layer, and in basal white ice which has probably been formed by assimilation of snow and ice debris from the foot of the ice cliff. These fabrics all show close symmetry relationships with the dimensional fabric (bubble lineation and foliation) and the deformation geometry (flow vectors, principal strain-rate orientations and orientation of the rock-ice interface) and are therefore "imposed" fabrics controlled by deformation.

The observed weakening of the single maximum in the optic-axis fabric from the base of the glacier to the surface appears to be related to the decreasing intensity of shear deformation. However, the rotation of the maximum about the flow vector cannot be explained satisfactorily. Kizaki ( 1969 ) has suggested that increase in grain-size of deforming glacier ice is correlated initially with rotation of the single maximum away from the pole to the controlling plane and, at a later stage, with increase in the number of maxima and further rotation. Both of these processes are attributed to the de-orientating effects of annealing recrystallization. Comparison of the Meserve Glacier ice samples with those examined by Kizaki suggests that the near-surface ice of Meserve Glacier is too fine-grained for multiple-maximum fabrics to develop, but it would be expected to show rotation of the single maximum, as observed in the bore-hole samples. Fabrics of coarser-grained ice near the ice-rock interface also show some rotation of the single maximum about the flow vector. Kizaki suggested that rotated maxima show certain preferred or stable positions with respect to the pole to the controlling shear plane, but the Meserve Glacier data are insufficient to substantiate this hypothesis.

In the near-surface ice of the Meserve Glacier tongue, the optic-axis fabrics do not show close symmetry relationships with the dimensional fabric or with the principal strain-rate orientations (averaged over $200 \mathrm{~m}$ from surface measurements). Deformation rates are not sufficiently high to re-orientate the relict bubble lineation, but the recrystallization mechanism producing the optic-axis fabric patterns is controlled to some degcee by deformation as indicated by the close relationship of the patterns to the flow vector.

The observed close relationships in symmetry between optic-axis fabric, dimensional fabric and deformation symmetry in ice subjected to relatively high strain-rates and the lack of correlation between these elements in ice subjected to relatively much lower strain-rates 
are consistent with the author's observations in temperate glacier ice (Anderton, 1970). Where dimensional and optic-axis fabrics are closely related in symmetry, the fabrics show direct control by deformation and the optic-axis fabric can be used to interpret deformation conditions, but where these fabric elements are divergent, the optic-axis fabrics, even when strongly developed, show indirect control by deformation and are not reliable indicators of deformation conditions. It appears that the characteristic optic-axis fabric patterns developed by glacier flow are determined by stress state, by temperature regime and by grain-size which is in part a function of stress level, in part a function of temperature, and must be influenced by initial grain-size and texture prior to deformation. Where stress state and temperature regime are relatively constant, increase in stress level has the effect of rotating fabric patterns towards closer coincidence with symmetry of the stress field and generally leads to strengthening of the fabric pattern.

It is likely that the symmetry of optic-axis fabrics in deforming glacier ice is related to the symmetry of the movement picture (or plan) which is defined in structural petrology as the pattern of small-scale movements resulting in the observed gross deformation (Turner and Weiss, I 963 ). This is supported by experimental deformation of ice in the laboratory (Kamb, 1972). According to this hypothesis, crystallographic fabrics reflect the symmetry of movement and not the symmetry of the stress field. The mechanism of deformation cannot be determined from the crystallographic fabric alone. Thus the strong single-maximum fabric of the Meserve Glacier ice supports the hypothesis that the flow occurs primarily by basal glide of individual ice crystals (combined with recrystallization to permit long-continued flow), but the fabric evidence alone cannot be taken as proof that only this process of flow is occurring. A similar fabric is evident in the amber ice which probably deforms to a considerable extent by grainboundary creep.

The single-maximum fabric has not been produced experimentally under deformation conditions comparable to glacier flow. Kamb (1972) has produced a two-maximum fabric in ice of similar grain-size to the Meserve Glacier ice, deformed under simple shear similar to the deformation at the base of Meserve Glacier, but at higher temperatures. One of these maxima is identical to the naturally occurring single-maximum and Kamb suggested that the single-maximum fabric may be produced by gradual rotation of the unstable second maximum into coincidence with the primary maximum during long-continued flow. Kamb also postulated that syntectonic recrystallization under long-continued flow involves mechanisms which are not yet understood and are not reproduced in laboratory experiments, and that fabrics similar to those produced experimentally should be produced only in the early stages of glacier deformation. Meserve Glacier could provide a means of testing this hypothesis by tracing the sequence of optic-axis fabrics developed along a flow line in the basal layer of white ice which has been incorporated relatively recently by assimilation of snow and ice debris.

\section{Acknowledgements}

This work was supported in part by National Science Foundation Grants GA-205 (1965-66 field season) and GA-532 ( $1966-67$ field season) awarded to the Ohio State University Research Foundation and the Institute of Polar Studies. Thanks are due to Dr G. Holdsworth, who initiated the basic programme of investigations of Meserve Glacier, for his co-operation and advice. Assistance in the field from R. Carnein and M. Fenton is gratefully acknowledged. The Institute of Polar Studies provided cold laboratory facilities for examination of the ice samples. Typing and draughting facilities were provided by the Ministry of Works, New Zealand.

MS. received 4 July 1973 


\section{REFERENCES}

Anderton, P. W. r970. Deformation of surface ice at a glacier confluence, Kaskawulsh Glacier. (In Bushnell, V. C., and Ragle, R. H., ed. Icefield Ranges Research Project. Scientific results. Vol. 2. New York, American Geographical Society; Montreal, Arctic Institute of North America, p. 59-76.)

Aufdermaur, A. N., and others. 1963. Kristallachsenlagen in Hagelkörnern, von A. N. Aufdermaur, R. List, W. C. Mayes und M. R. de Quervain. Zeilschrift für angewandte Mathematik und Physik, Vol. I4, Fasc. 5, p. $574-89$

Bull, C. B. B., and Carnein, C. R. 1970. The mass balance of a cold glacier: Meserve Glacier, south Victoria Land, Antarctica. [Union Géodésique et Géophysique Internationale. Association Internationale d'Hydrologie Scientifique.] [International Council of Scientific Unions. Scientific Committee on Antarctic Research. International Association of Scientific Hydrology. Commission of Snow and Ice.] International Symposium on Antarctic Glaciological Exploration (ISAGE), Hanover, New Hampshire, U.S.A., 3-7 September I968, p. 429-46.

Goldthwait, R. P. ig6o. Study of ice cliff, Nunatarssuaq, Greenland. U.S. Snow, Ice and Permafrost Research Establishment. Technical Report 39.

Gow, A. J. r970. Preliminary results of studies of ice cores from the $2164 \mathrm{~m}$ deep drill hole, Byrd station, Antarctica. [Union Géodésique et Géophysique Internationale. Association Internationale d'Hydrologie Scientifique.] [International Council of Scientific Unions. Scientific Committee on Antarctic Research. International Association of Scientific Hydrology. Commission of Snow and Ice.] International Symposium on Antarctic Glaciological Exploration (ISAGE), Hanover, New Hampshire, U.S.A., 3-7 September 1968, p. 78-90.

Holdsworth, G. r969. Primary transverse crevasses. Fournal of Glaciologv, Vol. 8, No. 52, p. 107-29.

Holdsworth, G. Unpublished. Mode of flow of Meserve Glacier, Wright Valley, Antarctica. [Ph.D. thesis, Ohio State University, I969.]

Holdsworth, G., and Bull, C. B. B. 1970. The flow law of cold ice: investigations on Meserve Glacier, Antarctica. [Union Géodésique et Géophysique Internationale. Association Internationale d'Hydrologie Scientifique.] [International Council of Scientific Unions. Scientific Committee on Antarctic Research. International Association of Scientific Hydrology. Commission of Snow and Ice.] International Symposium on Antarctic Glaciological Exploration (ISAGE), Hanover, New Hampshire, U.S.A., 3-7 September 1968, p. $204^{-1} 6$.

Kamb, W. B. 1972. Experimental recrystallization of ice under stress. (In Heard, H. C., and others, ed. Flow and fracture of rocks, edited by H. C. Heard, I. Y. Borg, N. L. Carter and C. B. Ralsigh. Washington, D.C., American Geophysical Union, p. 2 I I-4I. (Geophysical Monograph 16.$)$ )

Kizaki, K. 1969. Ice-fabric study of the Mawson region, east Antarctica. Fournal of Glaciology, Vol. 8, No. 53, p. $253-76$.

Rigsby, G. P. I96o. Crystal orientation in glacier and in experimentally deformed ice. Fournal of Glaciology, Vol. 3 , No. 27, p. $589-606$.

Shumskiy, P. A. I955. Osnovy strukturnogo ledovedeniya. Petrografiya presnogo l'da kak metod glyatsiologischeskogo issledovaniya. Moscow, Izdatel'stvo Akademii Nauk SSSR. [English translation: Principles of structural glaciology: the petrography of fresh-water ice as a method of glaciological investigation. Translated from the Russian by David Kraus. New York, Dover Publications, 1964.]

Steinemann, S. [1956.] Flow and recrystallization of ice. Union Géodésique et Géophysique Internationale. Association Internationale d'Hydrologie Scientifique. Assemblée générale de Rome 1954. Tom. 4, p. 449-62.

Steinemann, S. 1958. Experimentelle Untersuchungen zur Plastizität von Eis. Beiträge zur Geologie der Schweiz. Geotechnische Serie. Hydrologie, $\mathrm{Nr}$. 10.

Turner, F. J., and Weiss, L. E. 1963 . Structural analysis of metamorphic tectonites. New York, McGraw-Hill. 